\title{
0592. Metabolic acidosis induced by haemorrhage and hydrochloric acid generates different cardiorespiratory responses
}

G Sabbatini*, A Dyson, M Singer

From ESICM LIVES 2014

Barcelona, Spain. 27 September - 1 October 2014

\section{Introduction}

Metabolic acidosis is classically thought to induce an enhanced ventilatory pattern, irrespective of the underlying aetiology.

\section{Objectives}

To induce a similar level of acidaemia in a rat model, by either infusion of an acidic solution or by blood withdra- wal, and to assess the physiological responses to these insults.

\section{Methods}

Isoflurane-anaesthetised, tracheotomized rats were instrumented with left common carotid arterial and right jugular venous lines for blood sampling/BP monitoring and fluid/ blood administration, respectively. Oxylite ${ }^{\mathrm{TM}}$ probes

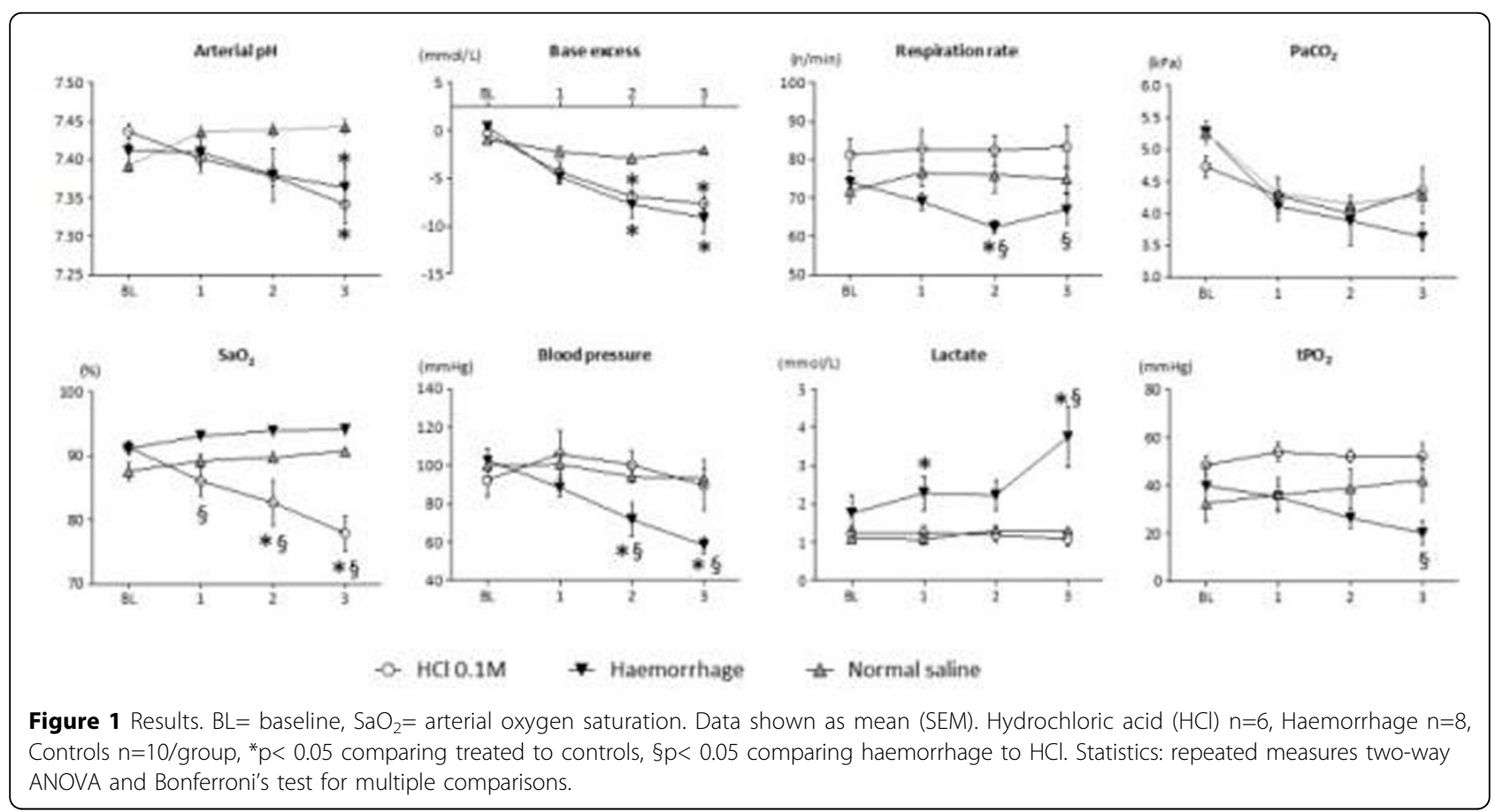

University College London, Bloomsbury Institute of Intensive Care Medicine,

London, United Kingdom

(c) 2014 Sabbatini et al; licensee Springer. This is an Open Access article distributed under the terms of the Creative Commons Attribution License (http://creativecommons.org/licenses/by/2.0), which permits unrestricted use, distribution, and reproduction in any medium, provided the original work is properly cited. 
(Oxford Optronix, UK) placed in thigh muscle were used to monitor tissue oxygen tension $\left(\mathrm{tPO}_{2}\right)$. Animals were subjected to either continuous $0.1 \mathrm{M}$ hydrochloric acid $(\mathrm{HCl})$ infusion or $60 \%$ withdrawal of estimated blood volume in six $10 \%$ steps over three hours to induce an equivalent fall in arterial base excess (BE). All animals (including a control group) received $n$-saline throughout. Hourly measurements were made of haemodynamics, $\mathrm{tPO}_{2}$ and arterial blood gas analysis.

\section{Results}

\section{See figure 1.}

$\mathrm{HCl}$ induced a metabolic acidosis with arterial hypoxaemia yet a preserved muscle $\mathrm{tPO}_{2}$, no tachypnoea nor fall in $\mathrm{PaCO}_{2}$. By contrast, haemorrhage to achieve a similar acidaemia, resulted in significant falls in blood pressure and $\mathrm{tPO}_{2}$, hyperlactataemia, a small rise in $\mathrm{SaO}_{2}$ and a decrease in respiration rate with a concomitant fall in $\mathrm{PaCO}_{2}$ probably related to higher tidal volumes.

\section{Conclusions}

Tissue hypoperfusion (and not just acidaemia per se) is an important component that triggers an enhanced ventilatory drive.

Published: 26 September 2014

doi:10.1186/2197-425X-2-S1-P36

Cite this article as: Sabbatini et al:: 0592. Metabolic acidosis induced by haemorrhage and hydrochloric acid generates different

cardiorespiratory responses. Intensive Care Medicine Experimental 2014

2(Suppl 1):P36.

\section{Submit your manuscript to a SpringerOpen ${ }^{\mathcal{O}}$ journal and benefit from:}

- Convenient online submission

- Rigorous peer review

- Immediate publication on acceptance

- Open access: articles freely available online

- High visibility within the field

- Retaining the copyright to your article

Submit your next manuscript at $>$ springeropen.com 